\title{
The Impact of Economic Development upon the Lives of Women in Developing Countries and Possible Alternatives with Special Reference to Sri Lanka
}

S. Medagama, ${ }^{1}$

SLJDA 2015 (5): 109-124

\begin{abstract}
This paper discusses the impact of development programmes on the lives of women with regard to two major development programmes already implemented. i.e Mahaweli, and IPZ. It further deliberates how development programmes have integrated women into development thrust. The impact on access to resources, technology, literacy, visibility, and triple roles was the focus of the study. The paper concludes that economic development has a differential impact upon the lives of women and that it has not contributed in reducing inequalities. The findings are applicable in the exercise of designing of future endeavours towards empowering women.
\end{abstract}

Key words: Economic Development, Developing Countries, Mahaweli Development Programme, Economic re-structuring programme

\section{Introduction}

The relationship between women and economic development is a complex issue. It has to be evaluated from the standpoint of the realities of women's lives. Development in developing countries popularly known as the Third World has been concerned not only with market growth but also with State-led development and poverty alleviation programmes. The countries of this region have undergone drastic changes lately in their economies and provide a wider range of development experience. The concept of gender equity is used as a yardstick to gauge the impact of development upon women.

1 Started his career as a researcher in Sri Lanka and has served in many parts of the country, carrying out research activities with teams consisting of both foreign and local researchers. He has served the Agrarian Research and Training Institute as a researcher. In 1986, he joined the Sri Lanka Institute of Development Administration (SLIDA), as a consultant and has 29 years of experience in the fields of training, research and consultancy. He has also served as a visiting lecturer to the University of Colombo, Rajarata University and University of Sri Jayawardenepura. He holds a B.A.(Hons) in Political Science, University of Peradeniya, a Diploma in Purchasing and Supply (DPS) North London University UK, Post Graduate Diploma in Distance Education (PGDDE) Indian Gandi Open University) and a MA in Gender and International Development Warwick University UK.He is also a Corporate Member, Institute of supply and Materials Management(MISMM) Sri Lanka. 
Prior to 1970s, it was thought that economic development affects men and women alike. Women were not considered participants of development prior to 1970s. When it became apparent that economic development did not eradicate poverty through the trickledown effect, the problem of distribution and equality of benefits to various segments of the population became significant in development theories. As a result, the gender dimension to the study of development process came in.

The issue of women and development has been a topic for debate for nearly two and half decades since the declaration of Mexico in 1975. It was the work of Ester Boserup that led to the beginning of discussion on development and women. She argued that development has had a negative impact on women and has marginalized them in economically developing societies. (Boserup, 1970) Eventually, this idea of Boserup resulted in the conceptualisation of a strategy for integrating women in development. Since then, there has been a substantial flow of resources and personnel through development agencies to achieve the objective of integrating women in development in the developing countries.

Theories of development and feminist theories have burgeoned in recent years. They all agree on one point in relation to development and women. They agree that the cardinal point in uplifting the women's position in the development process should be the equitable distribution of resources and power. This paper concentrates on the economic development efforts of the South Asian region and how these development efforts have affected women with special reference to Sri Lanka which is a developing country. Three major issues considering women are discussed here.

The extent of the participation and integration of women in national development programmes. (Mahaweli Development Programme Structural Adjustment Programmes- Free Trade Zone)

- The nature of the development process and conditions under which women have been involved.

- The impact of development programmes on the situation of women with respect to:

- Equal access to assets, resources, knowledge and skills,

- Equitable gender division of labour within and outside the household, and Empowerment of women for controlling and using their resources. 
Outcomes of two major programmes formulated and implemented to develop the economy and integrate women are discussed. These two programmes are:

- Mahaweli Development Programme

- Economic Re-structuring programmes- Free Trade Zones

These two programmes were the most important programmes implemented by the Government of Sri Lanka to develop its economy. These have had far-reaching impacts both upon the Sri Lankan economy and the lives of the people. These are also the two major development programmes in which the majority of women were employed. These also have a relevance to other countries in the South Asian region. Most of the countries in the South Asian region are subjected to Structural Adjustment Programmes and are experiencing the results of those programmes. Therefore, the Sri Lankan experience in these development programmes can be termed as experiences of the other countries of the region.

\section{The impact of economic development on the lives of women}

It is evident that women participate in economic development programmes. In this process, one has to examine whether women's contribution has empowered them to have equal access to resources and control over their labour and lives and whether it has improved their quality of life. These aspects are analysed by looking into the economic development projects implemented in Sri Lanka. The economic development projects implemented in Sri Lanka have encompassed agriculture, industry, rural development, social policies and special programmes. There are two major development programmes that are important in this context.

\section{Mahaweli Development Programme}

- Economic Re-structuring Programmes (FTZ)

\section{Mahaweli Development Programme:}

Mahaweli is the name of the largest and the longest river in Sri Lanka. The Mahaweli Development Programme involved diverting this river to the dry zone in order to irrigate land. It is where most of the poor people lived. This was the priority number one project in Sri Lanka as it absorbed 35\% of the annual budget. The United Kingdom, Sweden, West 
Germany, Canada, Japan, Netherlands, World Bank, USAID, EEC, and UNICEF funded this project. Under this project, five major reservoirs were to be constructed. A large number of fertile lands were submerged by these reservoirs making people landless. They and the people in the dry zone and the landless were to be given land in the dry zone which were to be irrigated. It was anticipated that the transformation of this vast region in the dry zone would increase income, raise living standards, and promote the emergence of self-reliant peasant producers. It is within this context that one has to examine how women fared in this massive development programme.

\section{Access to resources}

Marginalisation of women in respect of access to resources in economic development in the developing countries is observed. Ownership of land is one of the key resources for entering into other economic and entrepreneurial activities. Land is the most important means of production in the Mahaweli project area. In the project area, the process of land settlement has eroded the existing rights of women to own land due to preference given to male succession over female. Land is allotted to the male heads of households. The assumption here is that the benefit will trickle down to the family, ie, to women from the male landowner. This is a clear sign of the gender insensitivity of the planners dealing with land issues in relation to women. This practice of male preference is seen in relation to agricultural projects implemented in the Sub-Saharan Africa. For example, in Kenya, in the Mwea irrigated rice settlements, women were deprived of access to their own plots. (Hanger and Morris, 1973)

Women were allotted lands only if they owned land in the areas that were submerged by the reservoirs. However, land was not given to poor women who were landless, depriving them of the means of production. They are therefore, more disadvantaged than men in poor families and subject to gender based discrimination. Since women did not have access to land they were denied participation in entrepreneurial activities. Poor women were particularly vulnerable in this respect.

Access to credit is another aspect that contributes to improve women's position in economic development. However, in developing countries, in the economic development process, poor women have been treated harshly. This can be seen in the development projects implemented in South Asia. Many self-employment projects aimed at women have failed due to this fact. The most disadvantaged women in terms of income are the self-employed producers in the urban and rural sectors who have been 
the target group of income generating programmes in the developing countries. Their lack of access to capital, credit, skills, technology and markets has worsened their situation. The planners of economic development programmes do not pay adequate attention to this aspect that will result in poor women going to moneylenders at exorbitant interest rates. This will again worsen the position of poor women. They are indebted to moneylenders all the time. This is the experience of Bangladesh. The Emergence of 'Grameem Bank' in Bangladesh is the classic example to show how women's position can be improved through access to credit. In Sri Lanka, one of the priority programmes known as 'People's Strength' (Janasaviya) aimed at alleviating poverty in rural women badly failed due to inadequate attention to access of credit by poor women.

\section{Dichotomy of work}

Boserup (1970) writing her book on Women's role in economic development holds the view that that economic development and modernisation negatively affect women. This is clear in the main economic project implemented in Sri Lanka. Women in the Mahaweli areas have followed their traditional pattern of domestic economic activities. They are involved in land preparation, weeding, transplanting, harvesting, winnowing, processing and preservation activities that are considered women's work. Gender role stereotypes have given way to the demands of the activities of the agricultural lands. However, women have been engaged in men's work as well, such as clearing jungles, cutting drains and roads, and preparing fields for the cultivation of paddy or subsidiary crops (Dias, 1989). The support services that have come along to help women in Mahaweli areas have also focused upon the gender stereotypes. Vocational training in relation to what they do (production and agriculture) has not been given. Instead, they have been given training on areas which have no direct relevance to what they do. Training has been given on dressmaking and bee keeping which are traditionally considered women's domain of work. These services have emphasized domestication of women.

\section{Double burden of women}

The positive impact of any development programme can be gauged by the extent to which it reduces women's workload. Women in developing countries carry a double or even triple burden of work as they are involved in housework, childcare, and subsistence food production, in addition to an expanding involvement in paid employment. This has proved true 
according to the Sri Lankan experience. Women's work has increased. They are engaged in a wide range of activities and they spend on average 14 to 15 hours a day on paddy cultivation, home gardening, animal husbandry and house work while men work 8 to 10 hours a day. Women seem to be officially invisible in the economy despite their contribution. In rural areas, women in agriculture work longer hours than their men. The strategies introduced increased the demand for women's labour and also increased their drudgery (Hazer and Sen, 1994).

\section{Access to technology}

This is another aspect of economic development which can affect women positively or negatively. Technology, to a greater extent serves to ameliorate women's double burden and improve their quality of life. According to the Sri Lankan experience, planners and administrators have deprived many women of the knowledge and skills required for the modernisation of agriculture by paying scant attention to the needs of the women in the Mahaweli areas. Training in agricultural management and water management has been given to the head of the household thereby excluding women from gaining knowledge and skills. Women have been offered programmes organized around the concept of domesticity. The programmes aimed at women were home gardening and training in sewing which were traditionally considered to be the woman's domain of work. These courses expected to make women better housewives rather than economic producers. It is argued that denial of technology to women is a universal phenomenon and that new technology goes to men and not to women when it is introduced. This fact holds true in the Mahaweli area as well. When weeding machines were introduced, those went to men despite the fact that women traditionally did weeding. When tractors were introduced for threshing purposes, these too went to men despite the fact that women too were traditionally involved in threshing. Women are increasingly vulnerable to marginalisation by the mechanisation of their traditional roles such as transplanting and postharvest operations. In Korea too this happened. (Yoon and Park, 1985) Women have been excluded from the decision making process, with regard to production, credit, marketing and technical know-how. This is true in the African context as well. When carts were introduced to lessen the burden of African women in collection of firewood, men took them. This negation of technology to women has accentuated women's drudgery. 


\section{Economic roles of women and control of income:}

Access to decision making and control of income is another aspect of empowering women. According to the experience of developing countries, exclusion of women from the decision making process with regard to production, credit, marketing and technology is observed. Women invariably engage in income generating activities in the economy. But, this income is subsumed in the family as family income and women have no control over it. Women have little or no control over family resources.

It is clear from the discussion so far that the Mahaweli economic development programme has not contributed to the betterment of women in Sri Lanka even though it involved women in cash crop cultivation. This enabled women to engage in income generating activities at an increasing workload. As a result, their lives have been negatively affected. The impact of this programme upon the lives of women can be summarized as follows.

- Displacement and Domestication of women.

- Marginalisation of women from the decision making process.

- Devaluation of women's economic roles.

- Non-consideration of gender equality.

- Economic development planning resting on patriarchal values.

- Poor women being exploited and their role being doubled or tripled.

From the above discussion, it is clear that even though women are involved in economic development, they occupy a marginal position in the process. This arises mainly from the assumptions of the planners and administrators about women and their involvement in the development process. Women get discarded from development planning. The sexist assumptions regarding women's role in development has brought about this predicament (Moser, 1991).

\section{Economic re-structuring programmes and women: (Structural adjustment programmes-sap)}

During the past decade, economies of many developing countries faced a severe debt crisis. To come out from this debt crisis these countries were forced to seek financial assistance from the IMF and the World Bank. As a result, these countries were given financial assistance from these two international organizations on drastic conditions. Among them, was the 
restructuring of the economy. Many developing countries restructured their economies under the pressure of IMF and the World Bank. These changes have affected the lives of people living in these countries. Structural adjustment programmes have mostly affected women. The impact of SAP on the lives of the women in developing countries is discussed under following headings.

- Reduction in Social Services

- Education and Literacy

- Impact on Employment

- Effects on Household Income

- Women in Agriculture

- Environment and Women

- Women and Export Led Industrialization (Free Trade Zones)

\section{Reduction in social services}

As mentioned earlier, the developing countries were under pressure from the IMF and World Bank to reduce the costs incurred in the public services provided. They were asked to cut public services provided such as health, education, welfare services and removal of subsidies on basic foodstuffs. Women were most affected by the cuts in these areas. Cuts in educational services affect women's literacy and schooling of girls. When cuts are on education, it is the girls who have to stop schooling first. "In most of the societies in the world women are considered both producers and carers. When prices of foods rise and wages fall under SAP, most women spend more time finding ways to satisfy her family's hunger, travelling further to cheaper shops or markets, preparing cheaper foods, and often eating less herself in order to feed her husband and children." (Structural Adjustment P.15)

Women are considered to be the providers of primary health and education. This is a common truth in most of the countries of the world, not just in the developing world. When cuts are introduced in these areas women are the first to suffer. Cut backs in health services have deteriorated the health services in many developing countries. In Latin America, preventable diseases such as influenza and diarrhoea account for $46 \%$ of deaths of women in the age group of 25-44 years. "New statistics on the well-being of the world's women, published in UNICEF's State of the World's Children, 1989, show the double disadvantage of being poor and female. In some societies female children have a lower 
nutritional status and higher mortality rates; they are likely to have been more affected by the general worsening of health conditions. Some half a million women die of "maternal causes" every year." (Impact of Structural Adjustment on Women, P. 27) "Dr. Halfdan Mahler, former Director General of WHO writing in the International Herald Tribune says "Lives of the majority of women of Asia, Africa and Latin America consist of ceaseless physical labour and too frequent childbearing. Maternity kills half a million women each year, deaths easily avoidable if health services were adequate. A woman in Africa has a life time risk of dying from pregnancy related causes 200 times higher than that of women in industrialized countries." (Impact of Structural Adjustment on Women, P.27)

Curtailment of food subsidies has affected many women in the developing countries. It has helped to increase malnutrition among women and children of poor families. For example, in Sri Lanka, with the introduction of SAP, food subsidy was curtailed. In Bangladesh, Gambia and Mexico, reduction in food subsidy has affected women.

\section{Education and literacy:}

Under the guidelines of the IMF and World Bank, many developing countries had to cut expenditure on schools and education. This has specially affected women. The enrolment of girl students to schools has declined dramatically. In the developing countries illiteracy is still a problem. This is so in the countries of Middle East, South Asia, and Africa. In these countries illiteracy rates are higher among women than men. Under patriarchal norms, women are not encouraged to study. Men are encouraged to study further.

When the school system suffers cuts, it is women who are the first to be affected by it. This can be illustrated by the Latin American example. Latin American countries have reported that a high dropout rate for women exists, due to economic factors. Scholarships are available to all, but more men take advantage of them. A study prepared by the UN Division for the Advancement of Women found that, there was a clear tendency for deterioration in the ratio of girls to boys in secondary education. Closure of schools and reduction of expenditure on education have deprived many women of the education facilities in the developing countries. But, this phenomenon is not seen in Sri Lanka. 


\section{Impact on employment:}

Under Structural Adjustment programmes, many women found employment in the industries started by the Multi-National Corporations in developing countries. This can be in a way, be seen as a positive result of the SAP. However, this aspect of SAP is much criticised. Women, working in these industries are low-paid and exploited. They work under bad working conditions.

\section{Effects on household income:}

Adjustment policies have affected the household income of poor families. Due to increase in food prices, rising inflation cuts in subsidies, incomes of poor families have come under immense pressure. This has become particularly sharp in women headed-families. In the presence of economic crises, it is the practice of most men of the African countries to migrate looking for better job opportunities leaving behind their wives and children. Her life becomes bitter when the husband migrates for new job opportunities. She has to provide food and household needs, maintain house with a lesser income. This becomes nightmarish with cuts in public services and food subsidies. If she is working, the burden is tripled. The fall in household income has reduced the purchasing power of rural women forcing her to work longer hours to find means to maintain the family. The most disadvantaged women in terms of income are the self-employed home-based producers in the rural sectors who have been the target group of income generating programmes. Their lack of access to adequate capital, institutional credit, skills, technology and markets has made their lives miserable. This is very much the picture of Sri Lanka.

\section{Women and cash crops:}

Many countries of Africa, to overcome debt crisis, switched over to growing cash crops for export, leaving aside growing food for local consumption. Under this move, women had to give up their roles in traditional agriculture. They were expected to work as wage labourers at a lower rate than men. This has made women work more hours than men. Women carry out these tasks in addition to their traditional food growing. This happened in Sri Lanka too in relation to Mahaweli Economic development programme. In the settlement areas under the Mahaweli scheme, women were expected to work in cash crop production at a lower wage rate than men. 


\section{Women and export-led industrialization: (Free Trade Zones)}

Under Structural Adjustment Programmes, liberalisation of economies of the developing countries was a common feature. These countries were willy-nilly compelled to bring in drastic changes into their economies. As a result, economies of these countries were liberalised. This happened in Sri Lanka in 1977. Under SAP, promotion of export-oriented industries was given high priority by the economies of these countries. One of the major economic development efforts under SAP was the establishment of Free Trade Zones. (FTZ) A large number of women were employed in these FTZs. The entry of large numbers of women into FTZs is of economic and social significance. Therefore, it is pertinent to see how it has affected the lives of women.

It is strongly believed that wage work liberates women from gender subordination. However, old forms of gender subordination are shown to be reproduced in new forms in certain work situations (Hazer, 1986). The participation of women in export-oriented industries has been analysed by several writers within the framework of the sexual division of gender subordination. It is evident from the studies carried out in relation to women working in Free Trade Zones in South-East Asia and South Asia that new forms of subordination and exploitation of women workers inside and outside the factory floor exist. These forms of subordination relate to the following areas.

- Women's work

- Wages

- Working conditions

- Health

- Living environment

- Vulnerability to social censure (Social Status)

- Sexual harassment

In most of the export-oriented industries women are concentrated in labour intensive jobs. The jobs carried out by women can be categorized as skilled, semi-skilled, and unskilled jobs. The majority of female workers are doing semi-skilled jobs in garment factories. They are mostly engage in machine sewing, hand sewing, knitting or assembling. This is very much so in Sri Lanka. Most of the women in these industries are doing age-sapping jobs. They are doing monotonous, eye straining 
work. As a result, they lose their youthfulness at a very young age. This has affected their social lives as well. Most of the young girls who come to work in these world market factories are from rural areas and very often from poor families. They come to work in expectation of earning some money for their future (marriage) as their parents cannot afford to do that for them. However, due to continuous engagement of these age-sapping jobs they lose their charm and thereby lose prospects of marriage. The girls who work in these factories have low social status. They are considered to be immoral and bad characters. As a result, they suffer from social censuring. This is very much the picture in Sri Lanka.

Their work status has also suffered. MNCs (Multi National Corporations) in trying to reduce production costs further, resort to subcontracting to subsidiaries through contractors. In this process women become 'contract workers' or 'casual workers' or 'home-based workers.'

Women in low-income families are compelled to accept 'piece work' at rates even below minimum wage levels. These 'home-based workers' in Sri Lanka work long hours, day and night, use family labour including child labour to meet production targets of industries. These products are more vulnerable to market instability.

The wages paid to women working in these factories are very low. To attract foreign investors wages have been kept low. It should be noted here that Sri Lanka provides the lowest wages in Asia. They are being increasingly exploited. This has been facilitated by making labour laws flexible in developing countries to attract investors. New laws have been passed to suppress women's struggles. Non-enforcement of labour legislation and discouragement of trade unions in the Free Trade Zones have ensured industrial peace for MNCs. For example, in the Philippines, during Marcos' time, laws were enacted to curb trade union activities. In Sri Lanka, even though union's rights are not blatantly denied, it is discouraged in a subtle way. These steps taken by the respective governments of developing countries have facilitated the multinational corporations exploitation of women working in their factories. Their poverty, low bargaining power and inexperience in work further bolster this exploitation to continue.

Women in the world market factories work under poor work conditions. Most of the women who work in these factories are women from 17 to 23 years of age. They are in their most productive age. However, due to appalling work conditions in these work places, their health conditions suffer. "Women in many countries work with toxic chemicals without warnings or safety equipment. Electronic workers peer through a 
microscope all day to inspect silicon chips. After a few years, their vision may be permanently blurred." (Structural Adjustment, 1992, P.24). In India, in SEEPZ, many women workers suffer from headaches, weakening of eyesight, deafness and general weaknesses.

Promotions are rare in these factories. Workers are given work targets to be achieved beyond their capacities. If these targets are not achieved they are fined. These punishments serve as a source of embarrassment and humiliation to the worker. For example, in Sri Lanka, in a certain garment factory, a black flag is put up on the desk of the worker until the target is met. Workers are sometimes punished for talking while at work by keeping them standing in front of the others. Sometimes workers are asked to run around the factory if they are found dozing or sleeping. A strict discipline is maintained with the possible threat of expulsion in regard to achievement of work targets.

Living environments of these working women are also deplorable. Most of the women working in these factories live in boarding places that have no basic amenities. This is so in the Philippines, Malaysia and Sri Lanka. This has also resulted in the deterioration of women's health.

Many women working in FTZ have been subjected to sexual harassment either by their supervisors or after work. (When going back to boarding places) In the work place, they are subjected to various forms of harassment ranging from pregnancy tests. If they are found pregnant, they get fired immediately.

The introduction of SAPs in the developing countries generated an informal sector. This sector is hardly covered by law. Many women are employed in the informal sector as casual workers, house assistants, and petty traders. Most of the women are exploited as the law is absent in this sector.

SAP programmes have to a certain extent, caused environmental degradation in the developing countries which affects women. In India, in the name of economic development, large extents of forestland are given for establishing Free Trade Zones. This has affected thousands of lives of people, especially women. As a result of denudation of forests, the springs have dried down causing rural women to walk long distance for water. Women are finding it difficult to find fodder for their animals. They have run short of fuel since they use wood as a source of fuel. These trends in economic development have made women's lives miserable. This is the picture of African countries as well. 
Traditional industries where the majority of women are employed are badly affected by SAP. One of the major local industries affected by SAP is the 'handloom' industry. Sri Lanka and India bear witnesses to this effect.

\section{Conclusion}

It is apparent from the discussion that economic development has had a differential impact upon the lives of women and that it has not contributed to reducing inequalities. It is also evident that it is the low-income families that are vulnerable to negative consequences of development programmes. SAP has adversely affected the quality of lives of women. Under these circumstances one cannot say that the economic development in these countries has improved the quality of lives of women.

Women in the agricultural sector have seen an increase in their workload. They have lost their land rights and continue to carry on gender stereotyped roles that undervalue their economic contribution. They are still invisible in official data plans.

It is also clear that gender division of labour is relatively unchanged and that the majority of women are confined to the lower levels of the socioeconomic hierarchy and that economic participation of women has not been congruent with economic independence.

National economic development policies have tended to conform to the western capitalist model of free enterprise in a society that is burdened with poverty and socio-economic inequalities. This has exposed men and women in poor families in the developing countries to unbridled market forces and exploitative production relations.

Oppressive economic structures perpetuate the poverty status of economically disadvantaged families and economic and social institutions reinforce gender subordination. Most women in all sectors of the economy tend to accept these structures thereby allowing the exploitation to continue.

It is important to question the nature of the economic development process into which women are integrated and to intervene in mainstream programmes to change structures that militate against wholesome development. New conceptual definitions and methodologies are necessary to capture the totality of women's work experience. 
Women's skills need to be improved on a similar scale to meet the demands of an increasingly technological environment by reducing the gender role stereotypes and an inequitable gender division of labour.

Women continue to have a low visibility in economic issues and their economic roles have not been recognized adequately. The need to mobilize women as participants of the economic development in relation to their needs is not reflected in economic development. The thinking of planners and administrators of developing countries have, to a certain degree contributed to the derogatory position of women in the economic development process. They are influenced by the Victorian gender role assumptions. The assumptions of men as breadwinners and women as dependent housewives, consumers of services and secondary earners have negatively affected women in economic development. The result of these assumptions can be seen in many development programmes carried out in the developing countries. The "choice" of scientific agriculture for men and home economics for women promotes the 'housewifisation.'

Mobilisation of women in economic development has not developed their capacity to take control of their lives.

Even though there are many negative results in relation to women's lives in the economic development of developing countries, there are positive results as well. Following are some of them. Entrance of a large number of women into the formal labour market, Economic independence (Greater freedom), Improved decision making (Developed capacity for self-determination), Improved social mobility, Improved sisterhood (Solidarity among women), Improved social status and Increased bargaining power.

\section{References:}

Afshar, Haleh (1991). Women, Development and Survival in the Third World, Longman.

Bardhan, Kalpana., Raju, Saraswati., Bagchi, Deipica (1993). Women and Work in South Asia, Regional Patterns and Perspectives, London and New York, Routledge.

Heyzer, Noeleen., Zen, Gita (1994). Gender, Economic Growth and Poverty: Market Growth and State Planning in Asia and the Pacific, Kali for women, pp. 246-278

Boserup, Ester. (1986). Women's Role in Economic Development, Aldershot, Gower.

Dias, Malsiri. (1989). Participation of Women in Community Action, UN Decade for women progress and Achievements of Women in Sri Lanka, Colombo, Karunaratne and Sons.

Gordon, A. April (1996). Transforming Capitalism and Patriarchy, U.S.A, Lnne Reinner.

Jahan, Jahan. (1995). The Elusive Agenda: Mainstreaming Women in Development, Bangladesh, The University Press Ltd. 


\section{S. Medagama}

Heyzer, Noeleen.(1986). Daughters in Industry: Work Skills and Consciousness of Women Workers in Asia, and Pacific Development Centre, pp. 184-207

Heyzer, Noeleen. (1986). Working Women in South-East Asia: Development, Subordination and Emancipation, Open University Press.

Heyzer, Noeleen., Zen, Gita. (1994). Gender, Economic Growth and Poverty: Market Growth and State Planning in Asia and the Pacific, Kali for women.

Jayaweera, Swarna. (1979).Women in the Economy: Status of Women, Sri Lanka, University of Colombo.

Momsen, J.H. (1991). Women and Development in the Third World, London Routledge:

Mohanty, Chandra T. (1991). Third World Women and the Politics of Feminism, Bloomington, Indiana University press.

Molyneux, Maxine. (1985). “Mobilization without Emancipation"? Women's interests, State and Revolution in Nicaragua" Feminist Studies 11 (2) :227-254.

Moser, Caroline. (1991). “Gender Planning in the Third World: Meeting Practical Gender Needs" Gender and International Relations, Indiana University press.

Schrijvers, Joke. (1993). “Towards increased autonomy? Peasant women's work in the North-Central Province of SriLanka" Women and Work in South Asia, Regional Patterns and Perspectives, London and New York, Routledge, pp.224-239.

Young, Kate. (1997). "Gender and Development" The Women, Gender \& Development Reader, London and New Jersey, Zed Books Ltd, pp.51-54.

Structural Adjustments-Who really pays? (1992) Public Interest Research Group, India.

Wijesinghe, (1997). "Administrative Reforms: International Perspectives and the Case of Sri Lanka". In Country Seminar for Secretaries of Ministers: Sri Lanka. Colombo: SLIDA, Government of Sri Lanka/CAPAM in partnership with the Commonwealth Secretariat. July 2001. (Mimeographed).

Wilmot A. Perera Commission. Government of Sri Lanka. Report of the Salaries and Cadre Commission 1961. Part I- Salaries and Connected Matters. Sessional Paper III1961. Colombo: Ceylon Government Press. 